\title{
Are Bt crops safe?
}

\author{
Mike Mendelsohn, John Kough, Zigfridais Vaituzis \& Keith Matthews \\ The US EPA's analysis of Bt crops finds that they pose no significant risk to the environment or to human health.
}

Bacillus thuringiensis $(B t)$ is a naturally occurring soil bacterium that produces proteins active against certain insects. Beginning in the mid-1990s, crop plants expressing $B t$ genes were commercialized in the United States. CrylAb and Cry1F Bt corn are effective in controlling certain pests of corn (European corn borer, corn earworm and southwestern corn borer), and Cry1Ac Bt cotton is effective in controlling certain pests of cotton (tobacco budworm, cotton bollworm and pink bollworm). Beyond the economic benefits to growers, the use of $B t$ corn and $B t$ cotton result in less risk to human health and the environment than chemical alternatives.

In 2001, the US Environmental Protection Agency (EPA; Washington, DC, USA) reassessed the four still registered, but expiring, Bt crops that had been accepted for agricultural use in the preceding six years (from 1995 to October 2001; Table 1). The Bt crop reassessment approvals included provisions to prevent gene flow from $B t$ cotton to weedy relatives, increase research data on potential environmental effects and strengthen insect resistance management.

From this reassessment, the EPA has determined that $B t$ corn and $B t$ cotton do not pose unreasonable risks to human health or to the environment. In this article, we summarize the supporting data and conclusions of the EPA. The complete reassessment document ${ }^{1}$, Biopesticides Registration Action Document (BRAD)-Bacillus thuringiensis Plant-Incorporated Protectants, which describes in detail the reassessment process, along with extensive references, can be found on the EPA website at h t t p://www.epa.gov/pesticides/ biopesticides/pips/bt_brad.htm.

\section{Federal oversight of $B t$ crops}

Consistent with the Coordinated Framework for Regulation of Biotechnology

Mike Mendelsohn, John Kough and Zigfridais Vaituzis are in the Office of Pesticide Programs and Keith Matthews is in the Office of General Council of the U.S. Environmental Protection Agency.

e-mail:mendelsohn.mike@epa.gov

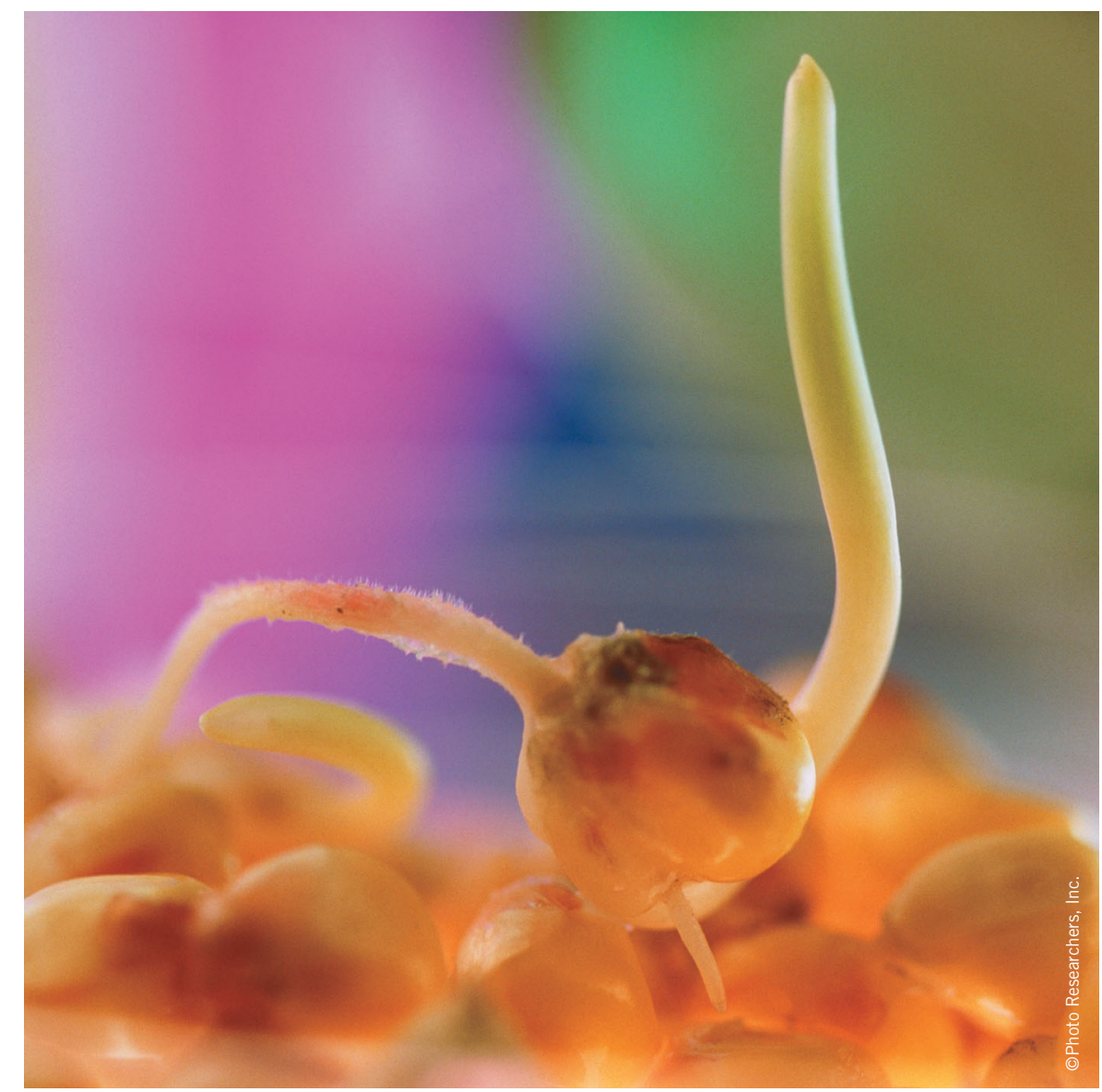

Seeds of concern or promise? Genetically modified corn has not been found by the EPA to pose significant health or environmental risks.

issued by the US Office of Science and Technology Policy in 1986 (51 FR 23302), genetically engineered (GE) crops with pesticidal traits fall under the oversight of the EPA, the US Department of Agriculture (USDA; Riverdale, MD, USA) and the US Food and Drug Administration (FDA; Rockville, MD, USA).

Using a voluntary consultation process, FDA determines whether foods and animal feeds developed from GE crops with pesticidal traits are as safe as their conventional counterparts. It does this by determining whether the companies producing them have answered all the appropriate questions about the new plant varieties, such as whether new allergens are present and whether there are increased levels of natural toxicants or perhaps reductions of important nutrients. Any changes in nutritional properties or crop processing or the presence of new allergens could require labeling to inform consumers of the important changes to the food or feed.

The USDA is responsible for protecting US agriculture against pests and diseases. All GE crops with pesticidal traits are considered plant pests until USDA concludes that the crop is not a plant pest and makes a determination of nonregulated status - that is, decides that the plant will no longer be regulated by USDA as a plant pest. Until that determination is made, the plants are subject to USDA oversight for importation, interstate movement and environmental release (for an outline, see ref. 2). 


\section{Box 1 Data required from EPA reassessment of $B t$ crops}

For the reassessment, the EPA required companies/applicants to provide the following data:

For all Bt crops:

- Analytical methods for detecting Bt residues in commerce.

- Protein expression level data in various plant organs, (expressed in terms of dry weight for consistency among different PIPs).

- Protein levels in soil.

- Field data regarding possible impacts on nontarget insects.

\section{For Bt corn:}

- Monarch butterfly studies evaluating fitness and reproductive costs from subchronic exposure to Bt corn.

- Chronic avian studies (e.g., poultry broiler feeding study).

- Insect resistance management data regarding (1) potential for north-to-south movement of Helicopvera zea (a polyphagous pest known as the corn earworm when a pest of corn and as the cotton bollworm when a pest of cotton), as movement of $H$. zea exposed to $B t$ from the corn belt and their overwintering in cotton regions could affect resistance; (2) impact of conventional chemical insecticide use on the effectiveness of a refuge producing susceptible insects; and (3) development of discriminating concentration bioassay for Cry $1 \mathrm{f}$ corn to help in monitoring for resistance in European corn borer, corn earworm and southwestern corn borer.

\section{For Bt cotton:}

- Insect resistance management data regarding (1) potential for north-to-south movement of cotton bollworm; (2) alternative plant hosts, to demonstrate whether they serve as an effective refuge in generating $B t$ susceptible insects; and (3) insect resistance management (IRM) value of sprays with different chemical insecticides used in conventional and Bt cotton.

For Cry1Ab corn and Cry1Ac cotton:

- Comparison of amino acid sequence to known toxins and allergens via stepwise 8-amino-acid analysis.

For MON810 Cry1Ab corn

- Processing and/or heat stability data.
The EPA's oversight focuses on the pesticidal substance produced (such as Bt protein or $\delta$-endotoxin) and the genetic material necessary for its production in the plant (such as cry genes). The EPA calls this unique class of biotechnology-based pesticides 'plant-incorporated protectants' (PIPs) and describes procedures specific for PIPs in "Procedures and Requirements for Plant-Incorporated Protectants"3. The EPA grants experimental use permits for field testing and registrations that permit the sale and use of pesticides in commerce under the Federal Insecticide, Fungicide, and Rodenticide Act (FIFRA) ${ }^{4}$. The EPA also issues tolerances or tolerance exemptions that permit pesticide residues in food and/or feed under the Federal Food, Drug, and Cosmetic Act (FFDCA) ${ }^{5}$.

\section{The reassessment}

The Bt Crops Reassessment was designed to ensure that the decisions about the renewal of these registrations were based on the most current health and ecological data. As such, the EPA incorporated recommendations made by the agency's FIFRA Scientific Advisory Panel (SAP), a US National Academy of Sciences (NAS) report on Genetically Modified Pest-Protected Plants issued in 2000 (ref. 6), and the findings of the 2000 administration-wide biotechnology review led jointly by the Council on Environmental Quality (CEQ; Washington, DC, USA) and the Office of Science and Technology Policy (OSTP; Washington, DC, USA).
During the reassessment, the EPA became aware of unexpected results from scientific studies and other information related to potential adverse effects on monarch butterfly populations and to the presence of an unapproved PIP in the US food supply. The agency reviewed data and consulted with experts regarding monarch butterfly safety and also worked with other US federal partners to respond to the reports of StarLink corn (Aventis' Cry9C corn) in the US food supply ${ }^{7}$.

The registration for StarLink corn was voluntarily cancelled and the registrations for Event 176 corn, the PIP variety most closely associated with effects on monarchs in the scientific literature, were allowed to expire while the reassessment efforts were proceeding. On the basis of the lessons learned from the StarLink episode, the EPA anticipates that the type of split pesticide registration that allowed StarLink to be used in animal feed, but not in human food, will no longer be considered a regulatory option.

Nine $B t$ crop PIPs had been registered by the EPA under FIFRA as of October 15, 2001; of these, the four still registered but expiring $B t$ crops were reassessed. Although the $B t$ Cry3A potato registration was not reassessed because its registration is nonexpiring, summary results were presented in the Agency's Fall 2001 reassessment. Data requirements for CrylAc cotton, two CrylAb corns and Cry1F corn are shown in Box 1.

In each case, a detailed scientific assessment of the $B t$ crop was undertaken to characterize each product (Table 2). Corn products registered at the EPA were transformed by protoplast electroporation to introduce the desired DNA or by methods involving bombardment of particles coated with DNA encoding the intended insert. Agrobacterium tumefaciens-mediated transformation was used for both cotton and potato products.

\section{Human health assessment}

$B t$ plant-incorporated protectants are proteins. Commonly found in the diet, proteins present little risk, except for a few welldescribed cases (such as food allergens, acute toxins and antinutrients). In addition, for the majority of $\mathrm{Bt}$ proteins currently registered, the source bacterium has been a registered microbial pesticide previously approved for use on food crops without specific restrictions. Because of their use as microbial pesticides, a long history of safe use is associated with many proteins found in these Bt products.

The EPA requires several types of data for the $B t$ plant-incorporated protectants to provide a reasonable certainty that no harm will result from the aggregate exposure to these proteins. The information is intended to show that the $B t$ protein behaves as would be expected of a dietary protein, is not structurally related to any known food allergen or protein toxin and does not show any oral toxicity when administered at high doses. These data consist of an in vitro digestion assay, amino acid sequence homology comparisons and an acute oral 
toxicity test. The acute oral toxicity test is done at a maximum-hazard dose using purified protein of the plant-incorporated protectant as a test substance. Because of limitations in obtaining sufficient quantities of pure protein test substance from the plant itself, an alternative production source of the protein is often used, such as the $B$. thuringiensis source organism or an industrial fermentation microbe.

The EPA believes that protein instability in digestive fluids and the lack of adverse effects using the maximum-hazard dose approach eliminate, in general, the need for longer-term testing of $B t$ protein plantincorporated protectants. Dosing of animals with the maximum-hazard dose, along with the product characterization data, should identify potential toxins and allergens and provide an effective means to determine the safety of these proteins.

In vitro digestibility assay. The in vitro digestibility test confirms that the protein is unstable in the presence of digestive fluids and that it is not unusually persistent in the digestive system. The digestibility test is not intended to provide information on the toxicity of the protein or imply that similar breakdown will happen in all human digestive systems. The assay may also provide information about the potential of a protein to be a food allergen. A limitation of the test is that it usually only tracks protein breakdown to fragments still recognized by the immunological reagents employed.
Although only gastric fluid is typically tested, because Cry protein is known to be stable in intestinal fluid, in the initial $B t$ products registered, gastric and intestinal fluids were examined separately. To track the breakdown of the product, the proteins are added to a solution of the digestive fluids and a sample is either removed or quenched at given time points (usually at time 0 , one to several minutes later and one hour later). The samples are then either subjected to electrophoresis in a sodium dodecyl sulfate-polyacrylamide gel (SDS-PAGE) and further analyzed by western (immunologic) blotting, or tested in a bioassay using the target pest. Each of the currently registered $B t$ proteins were tested and all were degraded in gastric fluid in 0-7 minutes.

Heat stability and amino acid homology. Two additional characteristics that may indicate possible relation to a food allergen are a protein's ability to withstand heat or food processing conditions, and its amino acid sequence as compared to those of known food allergens. For a few protein plantincorporated protectants registered to date, information is available on the heat or processing stability of the $\delta$-endotoxins, as indicated by bioactivity or immunological recognition after typical food processing. The CrylAb protein in one corn product and the CrylAc protein were demonstrated to be inactive in processed corn. A full-length amino acid sequence homology comparison for one Cry1 Ab product against the database of known proteins (allergens and gliadins) has been formally reviewed by the EPA.

Acute oral toxicity. Acute toxicity testing relies on the fact that toxic proteins generally express toxicity at low doses. Therefore, when the protein plant-incorporated protectants have no apparent effects in the acute oral toxicity test, even at relatively high doses, the proteins are considered nontoxic. The acute oral toxicity test is performed in mice with a pure preparation of the plant-incorporated protectant protein at doses from 3,280 to 5,000 $\mathrm{mg}$ per kilogram body weight. None of the tests performed to date have shown any significant treatmentrelated effects on the test animals.

Health conclusions. The mammalian toxicity data gathered by the EPA currently are sufficient to support the Bt plant-incorporated protectant registrations. None of the products registered at this time, all of which have tolerance exemptions for food use, show any characteristics of toxins or food allergens.

\section{Insect resistance management}

The unrestricted use of CrylAb and/or Cry $1 \mathrm{~F}$ in corn is likely to lead to the emergence of resistance in target insect pests unless measures are used to delay or halt its development. As some pests attack more than one crop, not only would the emergence of resistance affect the benefits of the $B t$ crop, but it also could affect the efficacy of $B t$ microbial formulations. The loss of $B t$

Table 1 History of registration of Bt crop plant-incorporated protectants (1995-2001)

\begin{tabular}{|c|c|c|c|c|}
\hline Year registered & Event $^{\mathrm{a}}$ and crop & Trade names & Companies & Status \\
\hline 1995 & Cry3A potato & NewLeaf & $\begin{array}{l}\text { Monsanto } \\
\text { (St. Louis, MO, USA) }\end{array}$ & No expiration date \\
\hline 1995 & Event 176 Cry $1 \mathrm{Ab}$ field corn & & $\begin{array}{l}\text { Syngenta } \\
\text { (Research Triangle Park, NC, USA) }\end{array}$ & Expired 4/1/01 \\
\hline 1995 & Event 176 Cry $1 \mathrm{Ab}$ field corn & & $\begin{array}{l}\text { Mycogen Seeds c/o } \\
\text { Dow AgroSciences } \\
\text { (Indianapolis, IN, USA) }\end{array}$ & Expired 6/30/01 \\
\hline 1998 & Event 176 Cry $1 \mathrm{Ab}$ popcorn & & Syngenta & Expired 4/1/01 \\
\hline 1995 & Cry 1 Ac cotton & BollGard & Monsanto & Expires 9/30/2006b \\
\hline 1996 & Event Bt 11 Cry $1 \mathrm{Ab}$ field corn & YieldGard & Syngenta & Expires 10/15/08 \\
\hline 1998 & Event Bt 11 Cry $1 \mathrm{Ab}$ sweet corn & Attribute & Syngenta & Expires 10/15/08 \\
\hline 1996 & Event Mon810 Cry1Ab corn & YieldGard & Monsanto & Expires 10/15/08 \\
\hline 1996 & MON801 Cry1Ab corn & & Monsanto & Voluntarily cancelled 5/1998 \\
\hline 1997 & DBT418Cry1Ac corn & DEKALB Bt-Xtra Corn & DeKalb/Monsanto & Voluntarily cancelled $12 / 20 / 2000$ \\
\hline 1998 & Event $\mathrm{CBH} 351$ Cry9C corn & StarLink & Aventis & Voluntarily cancelled 2/20/01 \\
\hline 2001 & TC1507 Cry1F field corn & $\begin{array}{l}\text { Herculex I Insect } \\
\text { Protection }\end{array}$ & $\begin{array}{l}\text { Mycogen Seeds c/o Dow } \\
\text { AgroSciences }\end{array}$ & Expires 10/15/08 \\
\hline 2001 & TC1507 Cry1F field corn & $\begin{array}{l}\text { Pioneer brand } \\
\text { Herculex I Insect } \\
\text { Protection }\end{array}$ & $\begin{array}{l}\text { Pioneer Hi-Bred (DuPont) } \\
\text { (Johnston, IA, USA) }\end{array}$ & Expires 10/15/08 \\
\hline
\end{tabular}

aEvent indicates a specific isolate of a plant that has been genetically transformed to introduce the desired DNA (in these cases, Bt cry genes) and resulting progeny from that isolate. bexternal unsprayed refuge option will expire 9/30/2004. 
as an effective pest management tool could have adverse consequences for the environment to the extent that growers might shift to the use of more toxic pesticides and a valuable tool for organic farmers might be lost. The emergence of resistance could also have significant economic consequences for growers of $B t$ crops. Therefore, the EPA continues to require the registrants to implement an insect resistance management (IRM) program to mitigate the possibility that pest resistance will occur.

Certain measures are required to delay or halt resistance from developing for $B t$ corn and $B t$ cotton. These include planting of a non- $B t$ refuge in conjunction with the planting of any acreage of $B t$ field corn or cotton (Table 3); agreements with growers which impose binding contractual obligations on the grower to comply with the refuge requirements; grower education; compliance assurance programs; monitoring for changes in target insect susceptibility to Bt Cry proteins; remedial action plans regarding measures the companies would take in the event that any insect resistance was detected; and annual reports on sales, IRM grower agreements results, compliance and educational programs. The companies registering the PIPs are responsible for seeing that that these measures are taken; failure of a farmer to follow the required IRM plan (measures) could result in the farmer losing the right to buy $B t$ seeds.

\section{Environmental assessment}

The EPA has conducted an environmental reassessment of the registered $B t$ plantincorporated protectants. The general topics covered include gene flow and the potential for weeds to develop if pollen from $B t$ crops plants were to fertilize other plants; horizontal gene transfer; expression of Bt Cry proteins in plant tissues; ecological effects, especially considering the available data on monarch butterflies; and fate of Bt Cry proteins in the environment

Gene flow and weediness. Under FIFRA, the EPA has reviewed the potential for gene capture and expression of the $B t$ endotoxins by wild or weedy relatives of corn, cotton and potatoes in the United States, its possessions or territories. Bt plant-incorporated protectants that have been registered to date have been expressed in agronomic plant species that, for the most part, do not have a reasonable possibility of passing their traits to wild native plants. Feral species related to these crops, as found within the United States, cannot be pollinated by the crops

Table 2 EPA assessment of $B t$ crop composition

\begin{tabular}{ll} 
Product & Plasmid \\
\hline Bt 11 Cry1Ab corn & pZO1502 containing the genes for Cry1Ab protein (cry $1 \mathrm{Ab}$ ); \\
& phosphinothricin acetyl transferase ( $p a t)$, conferring resistance to the \\
& herbicide glufosinate ammonium; and ampicillin resistance $\left(a m p^{r}\right.$ ). \\
& According to the registrant submission, before transformation, the \\
& the plasmid was digested with the endonuclease Notl to remove $a m p^{r}$. \\
& Although no data were submitted to confirm removal of the amp gene \\
& from the transforming DNA, subsequent analysis by the applicant showed \\
& that amp $p^{r}$ was not present in Bt11 corn genome. The cry $1 A b$ gene was \\
& also altered to increase its GC ratio for expression in corn and to increase \\
& its GC ratio for expression in corn and to truncate the original protein \\
& (to a size of $65 \mathrm{kDa}$ versus $130 \mathrm{kDa}$ for the full-length protein). Truncation \\
& improves expression while retaining insecticidal activity.
\end{tabular}

MON810 Cry1Ab corn

PV-ZMCT01, comprising plasmids PV-ZMBK07 and PV-ZMGT10 introduced together. Together these plasmids contain full-length copies of cry $1 \mathrm{Ab}$ and the markers $c p 4$ epsps and gox, which confer glyphosate resistance, and $n p t I l$, which confers kanamycin resistance. MON 810 expresses a truncated version of Cry $1 \mathrm{Ab} \delta$-endotoxin ( $63 \mathrm{kD}$ ) but does not express detectable levels of marker-gene products.

CrylF corn Linear Pmel fragment from plasmid pP8999, containing the genes for the cry $1 \mathrm{~F}(\mathrm{Cry} 1 \mathrm{~F}$ ) and Pat (pat) proteins and for kanamycin resistance $\left(k_{a n}{ }^{r}\right)$. A 6,235-base-pair Pmel fragment derived from this plasmid was purified and used in transformation to eliminate the $\mathrm{kan}^{r}$ gene. The $68-\mathrm{kD}$ Cry $1 \mathrm{~F}$ protein expressed in transformed maize lines is truncated as compared with the bacterial isolate from which it is derived. Expression of cry $1 F$ in line TC1507 is under the control of the maize polyubiquitin promoter, whereas the cauliflower mosaic virus (CaMV) 35 S promoter controls expression of pat.

Cry1Ac cotton

Cry3A potato contains the cry $1 A c$ gene as well as $n p t I l$. The full-length $130-\mathrm{kDa}$
Cotton line Coker 312 transformed with plasmid pV-GHBK04, which Cry 1 Ac Cry protein from $B$. thuringiensis subsp. kurstaki is expressed in cotton.

Russet Burbank line transformed with the plasmid pV-STBT02, which contained both the cry3A and npt/l genes. The $68-\mathrm{kD}$ Cry3A Cry protein from $B$. thuringiensis subsp. tenebrionis is expressed in potato.

Other information

Both field corn and sweet corn containing the plant-incorporated protectant descend from the original Bt 11 transformant. The purified tryptic core proteins from both plant and microbe were similar in molecular weight (by SDS-PAGE), western blot, ELISA, partial amino acid sequence analysis, lack of glycosylation, and bioactivity against European corn borer and corn earworm. This analysis justified use of microbially produced toxin as an analog for protein produced in plants for toxicity testing in mammals, which required large amounts of protein.

The marker genes are not present in MON810 corn, as shown by Southern blot analysis.

Hybridization patterns indicate that one full-length copy each of cryl $F$ and pat is integrated into the genome of line TC1507 and that no $\mathrm{kan}^{\mathrm{r}}$ DNA is integrated. One or two partial copies of cry $1 F$ are integrated into the genome and, from the sizes of the fragments detected, are most likely nonfunctional. 
Table 3 Insect resistance management refuge size requirements

\begin{tabular}{lll} 
Bt crop & Location, placement & $B t$ crop/non-Bt crop ratio \\
\hline Field corn & Corn belt & $80 \% B t / 20 \%$ non- $B t$ \\
Field corn & Cotton-growing areas & $50 \% B t / 50 \%$ non- $B t$ \\
Sweet corn & Crop destruction 30 days after harvest & No refuge required \\
Cotton & External unsprayed refuge (expiring in 2004) & $95 \% B t / 5 \%$ non- $B t$ \\
Cotton & External insecticide-sprayed refuge & $80 \% B t / 20 \%$ non- $B t$ \\
Cotton & Refuge embedded in Bt cotton field & $95 \% B t / 5 \%$ non- $B t$ \\
Cotton & Community refuge pilot & $\begin{array}{l}\text { Allows multiple growers to } \\
\text { share land for external }\end{array}$ \\
& & cotton refuges
\end{tabular}

In corn, the $20 \%$ refuge is required in areas outside cotton-growing regions, the $50 \%$ refuge in cotton-growing regions. This is because of the polyphagous pest Helicopvera zea, known as the corn earworm when a pest of corn and as the cotton bollworm when a pest of cotton.

(corn, potato and cotton) because of differences in chromosome number, phenology (that is, periodicity or timing of events within an organism's life cycle as related to climate, e.g., flowering time) and habitat. The only exception is the possibility of gene transfer from $B t$ cotton to wild or feral cotton relatives in Hawaii, Florida, Puerto Rico and the US Virgin Islands. The EPA has restricted the sale or distribution of $B t$ cotton in these areas to prevent the movement of the registered $\mathrm{Bt}$ endotoxin from $\mathrm{Bt}$ cotton to wild or feral cotton relatives.

Horizontal gene transfer. The EPA has evaluated the potential for horizontal gene transfer from $B t$ crops to soil microorganisms and has considered possible risk implications if this occurred. Several experiments published in the scientific literature have been conducted to assess the likelihood of horizontal gene transfer and have not detected gene transfer under typical conditions. Horizontal gene transfer has only been detected under conditions designed to favor transfer. In addition, the genes that have been engineered into the Bt crops are mostly found in, or have their origin in, soil inhabiting bacteria. Therefore, the EPA concluded that horizontal gene transfer is at most an extremely rare event and that the traits engineered into the $B t$ crops are already present in soil bacteria or are unlikely to have selective value for soil microorganisms.

\section{Environmental exposure}

For each of the four $B t$ crops, the nominal protein expression levels as determined by field and/or greenhouse conditions are described in Table 4 . The Bt protein values reported by each company may vary as a result of differences in the antibody-based reagents used for quantifying the $B t$ protein.
There are also differences caused by reporting $B t$ protein values based on tissue fresh weight. Although these differences may make it difficult to compare directly the tissue expression levels reported by different companies, the reported levels provide enough information for risk assessment purposes, especially when considered along with the reported tissue bioactivity values.

Soil. Soil organisms may be exposed to Cry proteins from current transgenic crops by exposure to roots, incorporation of above-ground plant tissues into soil after harvest or pollen deposition on the soil. Root exposure may occur by feeding on living or dead roots-or, theoretically, by ingestion or absorption after secretion of Cry proteins into the soil. In addition, evidence suggests that some soil components, such as clays and humic acids, bind Cry proteins in a manner that makes them recalcitrant to degradation by soil microorganisms, but without eliminating their insect toxicity. Therefore, exposure to Cry proteins bound to soil particles may also be a route of exposure for some soil organisms.

The possible accumulation of Cry proteins has been examined by determining ${ }^{a}$ ng/mg total protein. ${ }^{b}$ per dry weight. ${ }^{C}$ Tuber. degradation rates of Cry proteins, either in isolation or as expressed in the plant tissue and incorporated into the soil at a single point in time. Estimates of total Cry protein incorporated into the soil have been based on the biomass of total plant tissue, although it is not clear whether root biomass has been included in these calculations.

Most of the Cry protein deposited into soil by $B t$ crops is degraded within a few days, although a residue may persist in biologically active form for a much longer period of time (Table 5). It is also reported that the same amount of Bt Cry protein persists in soils that have been exposed to repeat $B t$ spray applications when compared to soil exposed to $B t$ crops. Although field tests of Cry protein degradation in soil under a range of conditions typical of $B t$ crop cultivation are needed to provide relevant data on persistence and natural variation, the limited data available do not indicate that Cry proteins have any measurable effect on microbial populations in the soil. Current studies of $B t$ in soil show no effect on bacteria, actinomyces, fungi, protozoa, algae, nematodes, springtails or earthworms. In addition, new plants planted in $B t$ Cry protein-containing soil do not take up the Bt protein.

Effect of CrylAb and Cry 1F corn on nontarget wildlife. In light of concerns that commercialization of $B t$ crops will effect the environment, the EPA reviewed new and existing data regarding nontarget wildlife effects for $B t$ corn with a special emphasis on Lepidoptera and monarch butterflies, and re-evaluated the data to support continued registration of $B t$ crops. The weight of evidence from the data reviewed indicated that there is no hazard to nontarget wildlife from the continued registration of $B t$ corn (Table 6).

The toxicity of $B t$ to butterflies is a well known and widely published phenomenon. For the purpose of its original risk assessment of $B t$ plant products, the EPA accepted

\begin{tabular}{|c|c|c|c|c|c|}
\hline Crop & $\begin{array}{l}\text { Leaf } \\
(\mathrm{ng} / \mathrm{mg})\end{array}$ & $\begin{array}{l}\text { Root } \\
\text { (ng/mg) }\end{array}$ & Pollen & $\begin{array}{l}\text { Seed } \\
\text { (ng/mg) }\end{array}$ & $\begin{array}{l}\text { Whole plant } \\
\text { (ng/mg) }\end{array}$ \\
\hline Cry1Ab corn Bt1 1 & 3.3 & $2.2-37.0^{\mathrm{a}}$ & $<90 \mathrm{ng} / \mathrm{g}^{\mathrm{b}}$ & 1.4 & NS \\
\hline Cry1Ab corn MON810 & 10.34 & NS & $<90$ ng/gb & $0.19-0.39$ & 4.65 \\
\hline Cry1F corn TC1507 & $56.6-148.9$ & NS & $113.4-168.2^{a}$ & $71.2-114.8^{\mathrm{a}}$ & $830.2-1572.7^{a}$ \\
\hline Cry3A potato & 28.27 & $0.39^{c}$ & NS & NS & 3.3 \\
\hline Cry1Ac cotton & 2.04 & NS & $11.5 \mathrm{ng} / \mathrm{g}$ & 1.62 & NS \\
\hline
\end{tabular}

All values reflect fresh tissue weight unless otherwise noted. NS, not submitted at the time of reassessment. 
Table 5 Cry protein fate in plant tissues and soil

\begin{tabular}{|c|c|}
\hline Protein & Bioactivity \\
\hline \multirow[t]{3}{*}{ Cry $1 \mathrm{Ab}$} & Tissue in the soil: $\mathrm{DT}_{50}, 1.6 \mathrm{~d}$; $\mathrm{DT}_{90}, 15 \mathrm{~d}$ \\
\hline & Tissue without soil: DT $_{50}, 25.6$ d.; DT90, 40.7 d \\
\hline & Purified protein in soil: $\mathrm{DT}_{50}, 8.3 \mathrm{~d}$.; $\mathrm{DT}_{90}, 32.5 \mathrm{~d}$ \\
\hline \multirow[t]{2}{*}{ CrylF } & Purified protein in the soil: $\mathrm{DT}_{50}, 3.13 \mathrm{~d}$ \\
\hline & Cry $1 \mathrm{~F}$ will degrade in the soil within $28 \mathrm{~d}$ (duration of this test) \\
\hline \multirow[t]{2}{*}{ Cry $1 \mathrm{Ac}$} & Purified protein in soil: DT $50,9.3-20.2 \mathrm{~d}$ \\
\hline & Ground, lyophilized Cry1A(c) cotton line 931tissue: $\mathrm{DT}_{50}, 41 \mathrm{~d}$ \\
\hline
\end{tabular}

$\mathrm{DT}_{50}$, time for $50 \%$ degradation; $\mathrm{DT}_{90}$, time for $90 \%$ degradation.

that $B t$ proteins could be toxic to Lepidoptera and relied exclusively on data on lepidopteran exposure to $B t$ Cry protein. Because exposure to butterflies and moths from the agricultural uses of $B t$ was not expected to be as high as that from the forest spraying of $B t$ for pests such as the gypsy moth (where no widespread and recurring or irreversible harm to lepidopteran insects was observed), $B t$ crops likewise were not expected to cause widespread or irreversible harm to nontarget lepidopteran insect populations.

The weight of evidence of currently published research data reviewed indicates that milkweeds in the corn fields and within 1 meter of cornfields are unlikely to be dusted with toxic levels of $B t$ pollen from the currently registered $B t$ corn varieties, MON810, Bt11 and TC1507. In addition, a variety of factors-the distribution of corn pollen within and outside corn fields, the distribution of milkweeds within corn habitat and other types of habitat, monarch oviposition and feeding behavior, limited temporal overlap between monarch larvae and pollen shed (and similar issues) in much of the corn growing regions of the United Statesindicate a low probability of adverse effects of $B t$ corn pollen on monarch larvae.

Data available to date indicate no difference in the number of total insects or the numbers of insects of specific orders between the transgenic crop plots and either the isogenic or the wild-type control crops. No shift in the taxonomic distribution of insects was seen, except in cases where the predators are dependent on the pest insect as prey as their major food source.

Toxicity data show that the only endangered species of any potential concern are in the Lepidoptera. The majority of endangered species in this order have very restricted habitat ranges, and do not feed on $B t$ crops or approach the planting areas closely enough to be exposed to toxic amounts of $B t$ pollen. Potential concern regarding range overlap with corn production was restricted to the Karner blue butterfly. However, the Karner blue host plant, the wild lupine, does not occur in corn fields and it appears highly unlikely that significant numbers of lupine would occur within a few (2) meters of corn field edges, where the toxic levels of corn pollen may be present. Moreover, there is only limited overlap between the time of the year when corn pollen is shed and the times when Karner blue larvae are likely to be present.

Effect of CrylAc cotton on nontarget organisms. The EPA determined that the nontarget organisms most likely to be exposed to the protein in transgenic cotton fields were beneficial insects feeding on cotton pollen and nectar and upland birds feeding on cotton seed. Thus, tests were required using representatives of those organisms (Table 6). Waterfowl, fish and aquatic invertebrate tests were waived because of probable lack of exposure. Studies on the effects of earthworms were not required. It was originally thought that because long-term exposure of soil organisms such as earthworms is possible when crop residues are incorporated or left upon the soil surface, the EPA would require studies evaluating effects upon earthworms. Data submitted indicate that Cry protein production ceases at senescence, allowing some time for protein degradation before harvest. Additionally, as the environmental fate data indicate that only $1.44 \mathrm{~g}$ of Cryl Ac protein per acre would enter the soil as a result of post-harvest incorporation of $B t$ cotton, and such proteins degrade rapidly, the potential for effects to nontarget soil organisms is not anticipated. Thus, an observable deleterious effect on earthworms is not expected to result from the growing of CrylAc-containing cotton plants.

Data available to date indicate that the transgenic cotton lines had no significant effect on populations of beneficial predator insects. However, the impact of chemical spray drift clearly affected the abundance of beneficial insects.

Cotton is an insect-pollinated crop, and only very small amounts of pollen containing the CrylAc protein can drift out of fields. Pollen containing CrylAc protein, at relatively very high dosages, was not toxic to the test species representative of organisms likely to be exposed to such pollen (e.g., lady beetles, green lacewings, honeybees). The habitats of the larvae of endangered Lepidoptera species in cotton-growing counties (Quino Checkerspot butterfly, Saint Francis' Satyr butterfly and Kern Primrose Sphinx moth) do not overlap with cotton fields. Hence, none of these larvae feed on cotton and thus they will not be exposed to Cry protein in pollen. The amount of pollen that would drift from these cotton plants onto plants fed upon by endangered or threatened species would be very small (if measurable) compared to the levels fed to the test species (Table 6). Therefore, the EPA does not expect that any endangered or threatened species will be affected by pollen containing the CrylAc protein.

In addition, because the EPA is imposing conditions for geographic areas that have sexually compatible wild or weedy relatives of cotton, the CrylAc protein gene cannot escape into related wild plants that could serve as a source of $B t$ pollen for plants on which endangered or threatened species may feed on in these areas. Because the EPA expects that no listed endangered species of Lepidoptera will be exposed to the Bt Cry protein expressed in cotton plants, and because the most probable exposure scenario does not appear to affect listed species, the agency believes that CrylAc Cotton will have no effect on listed species.

\section{Cry3A potatoes on nontarget wildlife}

Data presented in Table 6 indicates that Bt potato has no adverse effects on nontarget wildlife likely to be exposed to the crop. In addition, the data available to date indicate that beneficial arthropods were substantially more abundant in plots containing genetically modified potato plants and microbial $B t$ toxin applied to plant foliage than in those treated with conventional chemical insecticides. Aphid control was achieved in the plots containing transgenic potatoes solely through predation by natural enemies, whereas aphid populations rose to high levels in plots where beneficial arthropods were eliminated as a result of the conventional chemical insecticide treatment and no chemical aphid control was applied. 
Table 6 Nontarget organism toxicity study summaries for four different $B t$ crops

\begin{tabular}{|c|}
\hline Test materials and doses \\
\hline Cry $1 \mathrm{Ab}$ and Cry $1 \mathrm{~F}$ corn \\
\hline 100,000 ppm Cry $1 \mathrm{Ab}$ or Cry $1 \mathrm{~F}$ cornmeal \\
\hline or 50,000 ppm Cry $1 \mathrm{Ab}$ cornmeal \\
\hline 100 or $150 \mathrm{mg} / \mathrm{l}$ of Cry1 Ab corn pollen \\
\hline $100 \mathrm{mg} / \mathrm{l} \mathrm{Cry1F}$ corn pollen \\
\hline 20 ppm Cry1Ab protein \\
\hline $2 \mathrm{mg}$ Cry $1 \mathrm{~F}$ corn pollen or $640 \mathrm{ng}$ Cry $1 \mathrm{~F}$ protein/larva \\
\hline 20 ppm Cry $1 \mathrm{Ab}$ protein or $480 \mathrm{ppm}$ Cry $1 \mathrm{~F}$ protein \\
\hline 20 ppm Cry $1 \mathrm{Ab}$ protein or 320 ppm Cry $1 \mathrm{~F}$ protein \\
\hline 16.7 ppm Cry $1 \mathrm{Ab}$ protein or $480 \mathrm{ppm}$ Cry $1 \mathrm{~F}$ protein \\
\hline 200 ppm Cry $1 \mathrm{Ab}$ or 12.5 mg Cry $1 \mathrm{~F}$ protein/kg soil \\
\hline 200 ppm Cry $1 \mathrm{Ab}$ or $2.26 \mathrm{mg}$ Cry $1 \mathrm{~F}$ protein $/ \mathrm{kg}$ soil \\
\hline Cry1Ac cotton \\
\hline 100,000 ppm Cry1Ac cottonseed meal \\
\hline 20 ppm Cry 1 Ac protein \\
\hline 20 ppm Cry1Ac protein \\
\hline 20 ppm Cry1Ac protein \\
\hline 20 ppm Cry 1 Ac protein \\
\hline 200 ppm Cry1Ac protein \\
\hline Cry3A potato \\
\hline 50,000 ppm Cry3A potato tubers \\
\hline 100 ppm Cry3A protein \\
\hline 100 ppm Cry3A protein \\
\hline 100 ppm Сry3A protein \\
\hline 417 ppm Cry3A protein \\
\hline $100 \mathrm{mg}$ Cry3A protein/kg dry soil \\
\hline 200 ppm Cry3A protein \\
\hline
\end{tabular}

Nontarget organism

Result

The EPA has determined that Cry3A potatoes will not affect any threatened or endangered species. The known host range for the Cry3A protein is restricted to Coleoptera species. The listed coleopteran threatened or endangered species in potatogrowing areas are the American burying beetle, Hungerford's crawling water beetle, Mount Hermon June beetle, Northeastern Beach Tiger beetle, Puritan Tiger beetle and Valley Elderberry Longhorn beetle. These will not be exposed to Cry3A protein because their habitat does not overlap with potato fields and/or their larvae do not feed on potato tissue and will not be exposed to Cry protein in pollen or to toxic Cry3A levels in the soil. The amount of pollen that would drift from the potato plants onto plants fed upon by endangered or threatened species can be expected to be very small compared to the levels fed to the test species. Submitted data confirm that some coleopteran species tested are not affected, including lady beetles. Generally potato plants do not produce large amounts of pollen, which limits exposure. No endangered or threatened avian species feed on potatoes and no aquatic species are known to feed on potato plants.
Bobwhite quail

No treatment-related adverse effects

Daphnia magna (water flea)

Daphnia magna

Honey bee adults and larvae

Honey bee larvae

Ladybird beetle

Parasitic hymenoptera

Green lacewing

Collembola

Earthworms

Bobwhite quail

Honey bee larvae

Ladybird beetles

Parasitic hymenoptera

Green lacewing

Collembola

Bobwhite quail

Honey bee larvae

Ladybird beetles

Parasitic hymenoptera

Green lacewing

Earthworms

Collembola
No treatment-related adverse effects No treatment-related adverse effects No treatment-related adverse effects No treatment-related adverse effects No treatment-related adverse effects No treatment-related adverse effects No treatment-related adverse effects No treatment-related adverse effects No treatment-related adverse effects

No treatment-related adverse effects No treatment-related adverse effects No treatment-related adverse effects No treatment-related adverse effects No treatment-related adverse effects No treatment-related adverse effects

No treatment-related adverse effects No treatment-related adverse effects No treatment-related adverse effects No treatment-related adverse effects No treatment-related adverse effects No treatment-related adverse effects No treatment-related adverse effects

\section{Conclusions}

In the fall of 2001, the EPA completed a comprehensive reassessment of the timelimited registrations for all existing $B t$ corn and cotton PIPs. As part of this reassessment, the agency decided to extend the registrations with additional terms and conditions, including requiring confirmatory data to ensure protection of nontarget organisms and lack of accumulation of $B t$ proteins in soils, measures to limit gene flow from $B t$ cotton to wild (or weedy) relatives, and a strengthened IRM program, especially in regard to compliance.

The $B t$ cotton registration is now set to automatically expire on September 30, 2006 except for the external, unsprayed refuge option, which will expire September 30, 2004. The Bt corn registrations are now set to automatically expire on October 15, 2008. This reassessment was designed to assure that the decisions on the renewal of these registrations were based on the most current health and ecological data, and that the process was conducted in an open and transparent public process that incorporated sound and current science and substantial public involvement.

\section{ACKNOWLEDGMENTS}

Edward Brandt, Doug Gurian-Sherman, Linda Hollis, William Jordan, Suzanne Krolikowski, Sharlene Matten, Felicia Wu Morris, Willie Nelson, Alan Reynolds, Robyn Rose, Sasha Sicks, Brian Steinwand, Toby Tiktinski, Gail Tomimatsu, Robert Torla, Michael T. Watson and Chris Wozniak also contributed by being part of the EPA's Bt Crop Reassessment Teams.

1. Biopesticides Registration Action Document (BRAD)_Bacillus thuringiensis Plant-Incorporated Protectants, US EPA, October 15, 2001. http://www.epa.gov/pesticides/biopesticides/pips/bt_brad. htm

2. Title 7, Code of Federal Regulations, Part 340, Introduction of Organisms and Products Altered or Produced Through Genetic Engineering Which Are Plant Pests or Which There is Reason to Believe Are Plant Pests.

3. Title 40, Code of Federal Regulations, Part 174, Procedures and Requirements for Plant-Incorporated Protectants. http://www.epa.gov/pesticides/biopesticides/pips/index.htm

4. Title 7, United States Code, §§ 136-136y, Federal Insecticide, Fungicide, and Rodenticide Act.

5. Title 21, United States Code, §§ 301-397, Federal, Food, Drug, and Cosmetic Act.

6. US National Academy of Sciences. Genetically Modified Pest-Protected Plants: Science and Regulation (National Academies Press, Washington, DC, 2000). http://www.nap.edu/books/0309069300/ html/

7. StarLink Corn Regulatory Archive, US EPA. http://www.epa.gov/pesticides/biopesticides/pips/starlink_corn_archive.htm 